\title{
BACTERIOLOGICAL AND MOLECULAR STUDIES ON E. COLI ISOLATED FROM BROILER CHICKENS
}

\author{
WALID H. HASAN ${ }^{1}$; MOHAMMED A. A. ABD EL-LATIF ${ }^{2}$ AND \\ AHMED H. ABED \\ ${ }^{1}$ Bacteriology, Mycology and Immunology Department, Faculty of Veterinary Medicine, Beni-Suef \\ University, Egypt. \\ ${ }^{2}$ Animal Health Research Institute Dokki, El Fayoum Branch, Egypt.
}

Received: 17 September 2020; Accepted: 1 October 2020

\begin{abstract}
Avian colibacillosis is one of the most important diseases of chickens, resulting in high economic losses as well as high morbidity and mortality. In the current study, the prevalence of avian colibacillosis was studied in 200 broiler chickens obtained from different farms in Beni-Suef and El-Fayoum Governorates. A total of 200 pooling samples were collected aseptically from heart blood as well as the affected internal organs including airsacs, pericardial sac, liver, lung and ascetic fluids of slaughtered diseased and freshly dead broiler chickens. Bacteriological examination of the collected samples showed that a total of $58 E$. coli isolates were recovered with a prevalence of $29 \%$. The results of in-vitro antimicrobial susceptibility tests revealed that $E$. coli isolates showed high sensitivity to colistin sulphate only $(72.4 \%)$. On the other hand, high resistances were recorded to all other antimicrobials including cefotaxime sodium and florophenicol (96.6\% for each), apramycin, ciprofloxacin and gentamicin (91.4\% for each), enrofloxacin and lincomycin (91.4\% for each), streptomycin (89.7\%), sulphamethoxazol-trimethoprim and doxycycline $\mathrm{HCl}(77.6 \%$ for each) and spiramycin (75.9\%). Moreover, all E. coli isolates were MDR (100\%). PCR was applied on $10 \mathrm{E}$. coli MDR isolates for detection of 7 genes; 4 resistance-associated genes

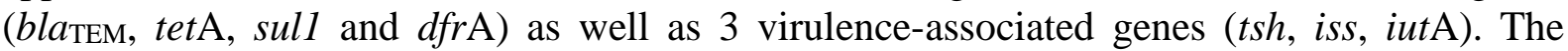
results revealed that $90 \%$ of isolates had at least 4 virulence genes while only $10 \%$ had not any gene. The gene bla TEM was the most prevalent (90\%) followed by iutA and sul 1 (70\% for each) then, iss and tetA (60\% for each). Meanwhile $d f r A$ and $t s h$ genes were represent in $40 \%$ and $30 \%$ of isolates, respectively.
\end{abstract}

Keywords: Broiler chickens, E. coli, antimicrobial susceptibility, multidrug resistance (MDR), resistance genes, virulence genes.

\section{INTRODUCTION}

Control of infectious diseases causing high economic loses in poultry industry is considered one of the major problems in the poultry farms (McKissick, 2006).

Corresponding author: AHMED H. ABED

E-mail address: aboabedelmasry@yahoo.com, ahmed.moawad@ vet.bsu.edu.eg

Present address: ${ }^{1}$ Bacteriology, Mycology and Immunology Department, Faculty of Veterinary Medicine, Beni-Suef University, Egypt.
Colibacillosis is caused by avian pathogenic $E$. coli (APEC) and it is considered a bacterial infection of great concern in the poultry industry. It is a widespread disease causing severe economic losses in the aviculture worldwide (Barnes et al., 2008). It indicates localized or systemic infections of APEC including many forms as colisepticemia, coligranuloma, airsacculitis/chronic respiratory disease (CRD), swollen-head syndrome, peritonitis/ascites, enteritis, cellulitis, 
salpingitis, omphalitis/yolk sac infection, panophthalmitis, synovitis, pericarditis, and osteomyelitis (Yue et al., 2018). Chickens of all ages are susceptible to colibacillosis but more common in young birds which are severely affected (Barnes et al., 2003). Colisepticemia is the most common form of colibacillosis which is responsible for high economic losses in aviculture in many parts worldwide (Saif, 2003).

E. coli is of the most important and frequently encountered avian bacterial pathogens causing a wide range of disease syndrome in birds which cause up to $30 \%$ of poultry mortality (Radwan et al., 2020). E. coli strains were classified by Russo and Johnson (2000) into 3 major groups including intestinal pathogenic strains, commensal strains and extra intestinal pathogenic E. coli (ExPEC) strains.

Although E. coli infections have been costly to the poultry industry, the exact virulence mechanisms used by these organisms to cause disease in birds remain interesting point of research. The presence of several virulence genes has been positively linked to the pathogenicity of APEC strains (Ewers et al., 2005). The establishment of PCR assays was to facilitate detection of the frequency with which the various virulence-associated genes occur in the resident APEC population; subsequently the isolates identified as the most highly pathogenic $E$. coli by PCR technique are used as the basis for the production of a powerful vaccine to be used against APEC infections. By researching the chain of infection, new and effective controls can be put in place to prevent the rapid spread of APEC (Ewers et al., 2004).

Since the introduction of antibiotics, there has been tremendous increase in the resistance in diverse bacterial pathogens (El-Seedy et al., 2019). Antimicrobial resistance of $E$. coli is a very important public health concern and of concern to poultry veterinarians (Radwan et al., 2020).
In-vitro antimicrobial sensitivity testing of veterinary pathogens provides valuable guidance to the veterinarian in the choice of appropriate drug treatment (Radwan et al., 2016). Moreover, it is very useful to detect the multidrug resistant (MDR) isolates. Therefore, the appropriate antibiotic should be selected on the basis of its sensitivity that could be detected by laboratory examination. Resistance of $E$. coli species to antimicrobials is widespread and of concern to poultry veterinarians. This increasing resistance has received considerable attention in Egypt and worldwide. Plasmids are the major vector in the spreading of resistance genes through bacterial population (Radwan et al., 2020). There is a wide variety of MDR E. coli, and PCR can be used to detect antimicrobial resistance genes in E. coli isolates.

The purpose of this study was designed to perform bacteriological and molecular characterization of pathogenic E. coli isolated from broiler chickens.

\section{MATERIALS AND METHODS}

\subsection{Chickens}

A total of 200 diseased Hubbard and Ross broiler chickens of different ages (2-5 weeks) obtained from different farms in Beni-Suef and El-Fayoum Governorates were subjected to the present study during the period from January 2017 up to December 2017. These chickens were subjected to clinical and postmortem examinations. The diseased chickens had multiple internal lesions including airsacculitis, pericarditis, hepatitis and ascites.

\subsection{Samples}

A total of 200 pooling samples were collected aseptically from diseased broiler. Pooling swab samples were collected aseptically from heart blood as well as the lesions in the internal organs including airsacs, pericardial sac, liver, lung and 
ascetic fluids of slaughtered diseased and freshly dead chickens.

\subsection{Bacteriological examination}

The collected samples were aseptically inoculated into MacConkey's broth and incubated aerobically at $37^{\circ} \mathrm{C}$ for $24 \mathrm{hrs}$. Then a loopful of the broth culture was streaked onto tryptone soya agar and MacConkey's agar and incubated aerobically at $37^{\circ} \mathrm{C}$ for $24-48 \mathrm{hr}$. The lactose fermenting (pink) colonies were inoculated onto eosin methylene blue agar medium and incubated at $37^{\circ} \mathrm{C}$ for $18-24 \mathrm{hrs}$ and confirmed as $E$. coli morphologically and biochemically using the standard biochemical tests described by Collee et al. (1996) and Quinn et al. (2002) using the following tests; oxidase, catalase, indole, methyl red, Voges Proskauer, citrate utilization, urease, $\mathrm{H}_{2} \mathrm{~S}$ production on TSI and nitrate reduction as well as sugar fermentation. Other nonbiochemical tests including motility test in semisolid agar medium and haemolysis on blood agar were applied.

\subsection{Serogrouping of $E$. coli isolates}

E. coli serogroups were identified serologically by slide agglutination test using standard polyvalent and monovalent $E$. coli antisera according to Quinn et al. (2002).

\subsection{Antimicrobial susceptibility testing}

Table 1: Primers of resistance and virulence genes used in PCR.

\begin{tabular}{|c|c|c|c|c|c|}
\hline \multicolumn{2}{|c|}{ Primer } & \multicolumn{2}{|r|}{ Primer sequence (5'-3') } & \multirow{2}{*}{$\begin{array}{c}\begin{array}{c}\text { Amplified } \\
\text { product }\end{array} \\
516 \mathrm{bp}\end{array}$} & \multirow{2}{*}{$\begin{array}{c}\text { Reference } \\
\text { Colom } \text { et al. (2003) }\end{array}$} \\
\hline \multirow{4}{*}{ 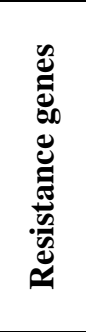 } & bla TEM & $\begin{array}{l}F \\
\boldsymbol{R}\end{array}$ & $\begin{array}{l}\text { ATCAGCAATAAACCAGC } \\
C C C C G A A G A A C G T T T T C\end{array}$ & & \\
\hline & tet $\mathbf{A}$ & $\begin{array}{l}F \\
R\end{array}$ & $\begin{array}{l}\text { GGTTCACTCGAACGACGTCA } \\
C T G T C C G A C A A G T T G C A T G A\end{array}$ & $576 \mathrm{bp}$ & Randall et al. (2004) \\
\hline & sul1 & $\begin{array}{l}F \\
R\end{array}$ & $\begin{array}{l}C G G C G T G G G C T A C C T G A A C G \\
G C C G A T C G C G T G A A G T T C C G\end{array}$ & $443 \mathrm{bp}$ & Sabarinath et al. (2011) \\
\hline & $d f r A$ & $\begin{array}{l}F \\
R\end{array}$ & $\begin{array}{l}\text { AGCATTACCCAACCGAAAGT } \\
\text { TGTCAGCAAGATAGCCAGAT }\end{array}$ & 817 bp & Huovinen et al. (1995) \\
\hline \multirow{3}{*}{ 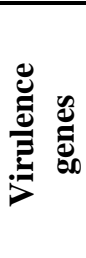 } & iutA & $\begin{array}{l}\boldsymbol{F} \\
\boldsymbol{R}\end{array}$ & $\begin{array}{c}\text { GGCTGGACATGGGAACTGG } \\
C G T C G G G A A C G G G T A G A A T C G\end{array}$ & $300 \mathrm{bp}$ & \\
\hline & iss & $\begin{array}{l}\boldsymbol{F} \\
\boldsymbol{R} \\
\end{array}$ & $\begin{array}{c}\text { ATGTTATTTTCTGCCGCTCTG } \\
\text { CTATTGTGAGCAATATACCC } \\
\end{array}$ & $266 \mathrm{bp}$ & Yaguchi et al. (2007) \\
\hline & $t s h$ & $\begin{array}{l}\boldsymbol{F} \\
\boldsymbol{R}\end{array}$ & $\begin{array}{l}\text { GGTGGTGCACTGGAGTGG } \\
\text { AGTCCAGCGTGATAGTGG }\end{array}$ & $620 \mathrm{bp}$ & Delicato et al. (2003) \\
\hline
\end{tabular}

All E. coli isolates were tested for their antimicrobial susceptibility to 14 different antimicrobial discs including; apramycin $(15 \mu \mathrm{g})$, ciprofloxacin $(15 \mu \mathrm{g})$, cefotaxime sodium $(30 \mu \mathrm{g})$, colistin sulphate $(10 \mu \mathrm{g})$, sulphamethoxazol-trimethoprim $\quad(25 \mu \mathrm{g})$, doxycycline $\mathrm{HCl}(30 \mu \mathrm{g})$, enrofloxacin $(5 \mu \mathrm{g})$, lincomycin $(10 \mu \mathrm{g})$, spectinomycin $(100 \mu \mathrm{g})$, fosfomycin $(300 \mu \mathrm{g})$, gentamycin $(10 \mu \mathrm{g})$, florophenicol $(30 \mu \mathrm{g})$, streptomycin $(10 \mu \mathrm{g})$

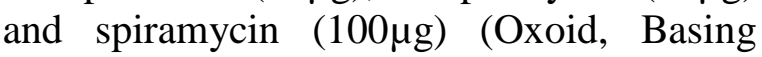
Stoke, UK). Antimicrobial susceptibility testing was applied using disc diffusion method on Muller Hinton agar according to CLSI (2016). The antimicrobial susceptibility was based on the induced inhibition zones according to the guidelines of the CLSI (2016). Resistance to three/or more antimicrobials of different categories was taken as multidrug resistance (MDR) according to Chandran et al. (2008).

\subsection{Polymerase chain reaction (PCR) for $E$. coli isolates}

PCR was applied on 10 MDR E. coli isolates for detection of 7 genes; 4 resistanceassociated genes (bla TEM, tet $\mathrm{A}$, sull and $d f r \mathrm{~A})$ as well as 3 virulence-associated genes (tsh, iss, iutA). DNA extraction, primers sequences, and amplified products for the targeted genes for $E$. coli isolates were illustrated in table (1). The temperature and time conditions of the primers during PCR were shown in table (2). 
Table 2: Cycling conditions of the different primers during PCR.

\begin{tabular}{|c|c|c|c|c|c|c|}
\hline Gene & $\begin{array}{c}\text { Primary } \\
\text { denaturing }\end{array}$ & $\begin{array}{c}\text { secondary } \\
\text { denaturing }\end{array}$ & Annealing & Extension & No. of cycles & $\begin{array}{c}\begin{array}{c}\text { Final } \\
\text { extension }\end{array} \\
\end{array}$ \\
\hline - $b l a_{\mathrm{TEM}}$ & $94 \mathrm{C} / 10 \mathrm{~min}$ & $94 \mathrm{C} / 45 \mathrm{sec}$. & $54 \mathrm{C} / 45 \mathrm{sec}$. & $72 \mathrm{C} / 45 \mathrm{sec}$. & 35 cycles & $72 \mathrm{C} / 10 \mathrm{~min}$. \\
\hline$-\quad t e t \mathrm{~A}$ & $94 \mathrm{C} / 5 \mathrm{~min}$ & $94 \mathrm{C} / 45 \mathrm{sec}$ & $50 \mathrm{C} / 45 \mathrm{sec}$. & $72 \mathrm{C} / 45 \mathrm{sec}$. & 35 cycles & $72 \mathrm{C} / 10 \mathrm{~min}$. \\
\hline - sul1 & $94 \mathrm{C} / 5 \mathrm{~min}$ & $94 \mathrm{C} / 45 \mathrm{sec}$. & $60 \mathrm{C} / 45 \mathrm{sec}$. & $72 \mathrm{C} / 45 \mathrm{sec}$. & 35 cycles & $72 \mathrm{C} / 10 \mathrm{~min}$. \\
\hline$-\quad d f r \mathrm{~A}$ & $94 \mathrm{C} / 10 \mathrm{~min}$ & $94 \mathrm{C} / 1 \mathrm{~min}$ & $50 \mathrm{C} / 1 \mathrm{~min}$. & $72 \mathrm{C} / 1 \mathrm{~min}$. & 35cycles & $72 \mathrm{C} / 10 \mathrm{~min}$. \\
\hline - iutA & 94C/5min. & 94C/30sec. & 63C/30sec. & 72C/30sec. & 35 cycles & $72 \mathrm{C} / 7 \mathrm{~min}$. \\
\hline - iss & $94 \mathrm{C} / 5 \mathrm{~min}$ & 94C/30sec. & $54 \mathrm{C} / 30 \mathrm{sec}$. & 72C/30sec. & 35 cycles & $72 \mathrm{C} / 7 \mathrm{~min}$ \\
\hline$-t s h$ & 94C/5min. & $94 \mathrm{C} / 45 \mathrm{sec}$. & $54 \mathrm{C} / 45 \mathrm{sec}$. & $72 \mathrm{C} / 30 \mathrm{sec}$. & 35cycles & $72 \mathrm{C} / 10 \mathrm{~min}$. \\
\hline
\end{tabular}

\section{RESULTS}

3.1. Prevalence of $E$. coli isolation in the diseased broiler chickens

Out of 200 diseased broiler chickens, $58 E$. coli isolates were recovered with an overall prevalence rate of $29 \%$.

\subsection{Serogrouping of $E$. coli isolates}

Out of $58 \mathrm{E}$. coli isolates, 7 O-serogroups were obtained. The serogroups $\mathrm{O}_{125}$ was the most prevalent represented 18 isolates $(31 \%)$ followed by serogroups $\mathrm{O}_{158}(n=14 ; 24.1 \%)$ and $\mathrm{O}_{55}(n=8 ; 13.8 \%)$. Then, the serogroup $\mathrm{O}_{78}(n=6 ; 10.3 \%)$. Afterthat, serogroups $\mathrm{O}_{1}$ $(n=4 ; 6.9 \%)$ and finally serogroups $\mathrm{O}_{15}$ and $\mathrm{O}_{8}(n=2 ; 3.4 \%$ for each). Moreover, there were 4 isolates $(6.9 \%)$ were untyped with the available antisera (Table 3$)$.

Table 3: E. coli serogroups recovered from broiler chickens.

\begin{tabular}{|c|c|c|}
\hline E. coli Serogroup & No. of tested isolates & $\%$ \\
\hline $\mathbf{O}_{125}$ & 18 & 31 \\
\hline$O_{158}$ & 14 & 24.1 \\
\hline $\mathrm{O}_{55}$ & 8 & 13.8 \\
\hline $\mathrm{O}_{78}$ & 6 & 10.3 \\
\hline $\mathbf{O}_{1}$ & 4 & 6.9 \\
\hline $\mathbf{O}_{15}$ & 2 & 3.4 \\
\hline O8 & 2 & 3.4 \\
\hline Total serotyped isolates & 54 & 93.1 \\
\hline Untyped & 4 & 6.9 \\
\hline Overall total & 58 & 100 \\
\hline
\end{tabular}

$\%$ : was calculated according to the overall total number (No.) of tested isolates $(n=58)$.

\subsection{Antimicrobial susceptibility testing}

Results of in-vitro susceptibility testing showed that $E$. coli isolates were highly resistant to most of the tested antimicrobials. The highest resistance was recorded against cefotaxime sodium and florophenicol (96.6\% for each) followed by apramycin, ciprofloxacin and gentamicin $(93.1 \%$ for each). Then, enrofloxacin and lincomycin
(91.4\% for each), streptomycin (89.7\%), sulphamethoxazol-trimethoprim and doxycycline $\mathrm{HCl}$ (77.6\% for each) and spiramycin $(75.9 \%)$. Finally, fosfomycin $(55.2 \%)$ and spectinomycin $(51.7 \%)$. On the other hand, they were highly sensitive to colistin sulphate only (72.4\%). MDR was detected in all the tested isolates (100\%) (Table 4). 
Table 4: Results of antimicrobial susceptibility testing of E. coli recovered from diseased broiler chickens.

\begin{tabular}{|c|c|c|c|c|c|c|c|}
\hline \multirow{3}{*}{ Antimicrobial disc } & \multirow{3}{*}{$\begin{array}{c}\text { Disc content } \\
(\mu \mathrm{g})\end{array}$} & \multicolumn{6}{|c|}{ E. $\operatorname{coli}(\mathrm{n}=58)$} \\
\hline & & \multicolumn{2}{|c|}{$\mathbf{R}$} & \multicolumn{2}{|c|}{$\mathbf{I}$} & \multicolumn{2}{|c|}{$\mathbf{S}$} \\
\hline & & No & $\%$ & No & $\%$ & No & $\%$ \\
\hline Apramycin & 15 & 54 & 93.1 & 4 & 6.9 & 0 & 0 \\
\hline Ciprofloxacin & 5 & 54 & 93.1 & 2 & 3.4 & 2 & 3.4 \\
\hline Cefotaxime sodium & 30 & 56 & 96.6 & 2 & 3.4 & 0 & 0 \\
\hline Colistin sulphate & 10 & 12 & 20.7 & 4 & 6.9 & 42 & 72.4 \\
\hline $\begin{array}{c}\text { Sulfamethoxazole- } \\
\text { trimethoprem }\end{array}$ & 25 & 45 & 77.6 & 7 & 12.1 & 6 & 10.3 \\
\hline Doxycycline $\mathrm{HCl}$ & 30 & 45 & 77.6 & 9 & 15.5 & 4 & 6.9 \\
\hline Enrofloxacin & 5 & 53 & 91.4 & 3 & 5.2 & 2 & 3.4 \\
\hline Lincomycin & 10 & 53 & 91.4 & 1 & 1.7 & 4 & 6.9 \\
\hline Spectinomycin & 100 & 30 & 51.7 & 7 & 12.1 & 21 & 36.2 \\
\hline Fosfomycin & 300 & 32 & 55.2 & 3 & 5.2 & 23 & 39.7 \\
\hline Gentamycin & 10 & 54 & 93.1 & 4 & 6.9 & 0 & 0 \\
\hline Florphenicol & 30 & 56 & 96.6 & 0 & 0 & 2 & 3.4 \\
\hline Streptomycin & 10 & 52 & 89.7 & 3 & 5.2 & 3 & 5.2 \\
\hline Spiramycin & 100 & 44 & 75.9 & 3 & 5.2 & 11 & 19 \\
\hline
\end{tabular}

2.4. Polymerase chain reaction (PCR) analyses of $E$. coli isolates

Regarding the resistance-associated genes, PCR results revealed that bla $a_{\text {TEM }}$ was the most prevalent gene present in $9 \mathrm{E}$. coli isolates $(90 \%)$ followed by sul $1(n=7 ; 70 \%)$, tetA $(n=6 ; 60 \%)$ and $d f r \mathrm{~A}(n=4 ; 40 \%)$ (Table 5 and Figs. 1-4).
On the other hand, PCR results of virulenceassociated genes revealed that iutA was the most prevalent gene present in $7 \mathrm{E}$. coli isolates $(70 \%)$ followed by iss $(n=6 ; 60 \%)$ and $\operatorname{tsh}(n=3 ; 30 \%)$ (Table 5 and Figs. $5-7)$.

Collectively, 9 isolates (90\%) had at least 4 genes while only one isolate $(10 \%)$ had not any gene.

Table 4: Prevalence and distribution of virulence and resistance- associated genes in the examined $E$. coli isolates.

\begin{tabular}{cccccccc}
\hline \multirow{2}{*}{ Gene } & \multicolumn{3}{c}{ Virulence genes } & \multicolumn{5}{c}{ Resistance genes } \\
\cline { 2 - 8 } & tsh & iss & iutA & bla & dfrA & sul1 & tetA \\
\hline 1 & - & + & - & + & + & + & + \\
\hline 2 & - & - & - & - & - & - & - \\
\hline 3 & + & - & + & + & - & + & - \\
\hline 4 & - & + & + & + & - & - & + \\
\hline 5 & - & + & + & + & + & + & + \\
\hline 6 & - & - & + & + & - & + & + \\
\hline 7 & - & + & - & + & + & + & + \\
\hline 8 & - & - & + & + & - & + & + \\
\hline 9 & + & + & + & + & + & + & - \\
\hline 10 & + & + & + & + & - & - & - \\
\hline Total & 3 & 6 & 7 & 9 & 4 & 7 & 6 \\
\hline$\%$ & 30 & 60 & 70 & 90 & 40 & 70 & 60 \\
\hline
\end{tabular}

$\%$ : was calculated according to the number (No.) of the tested isolates $(n=10)$. 


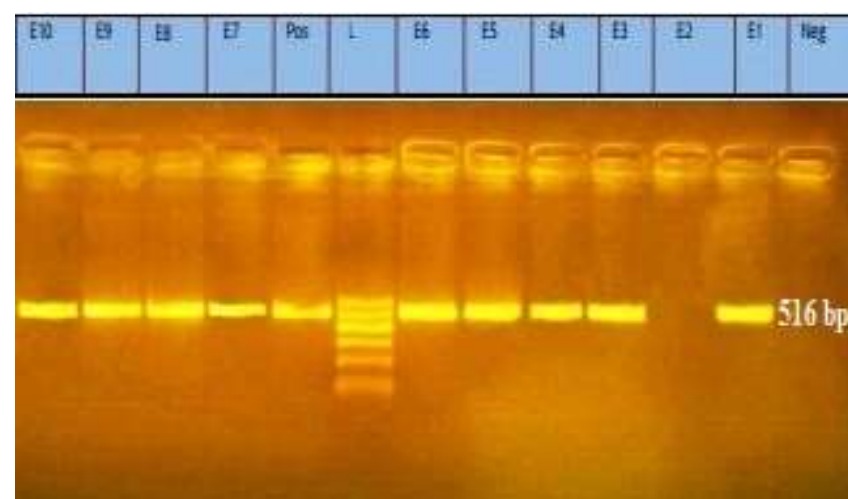

Fig. (1): PCR amplification of the $516 \mathrm{bp}$ fragment of bla TEM resistance gene from $10 \mathrm{E}$. coli isolates (1-10), Pos. (control positive), Neg. (control negative).

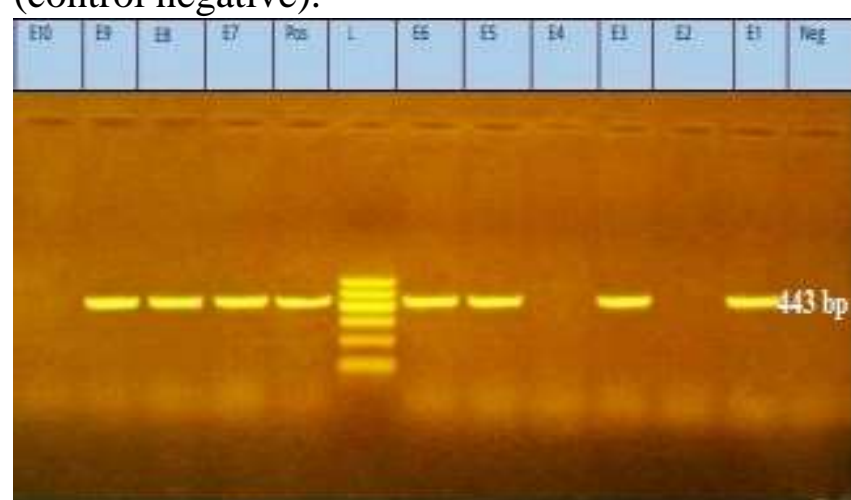

Fig. (3): PCR amplification of the $443 \mathrm{bp}$ fragment of sul1 resistance gene from $10 \mathrm{E}$. coli isolates (1-10), Pos. (control positive), Neg. (control negative).

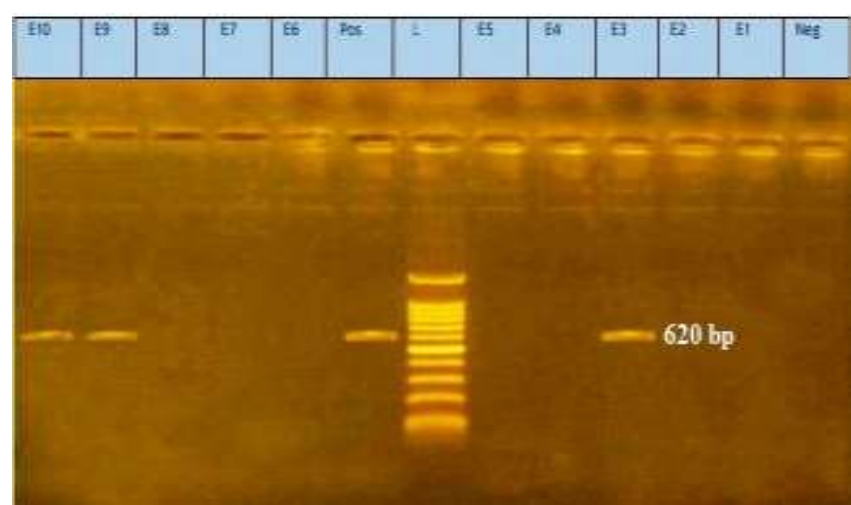

Fig. (5): PCR amplification of the $620 \mathrm{bp}$ fragment of $t s h$ virulence gene from $10 \mathrm{E}$. coli isolates (1-10), Pos. (control positive), Neg. (control negative).

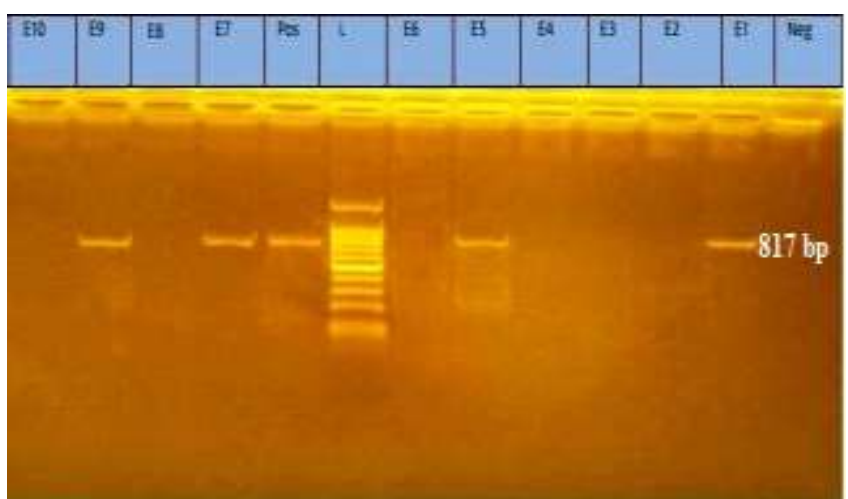

Fig. (2): PCR amplification of the $817 \mathrm{bp}$ fragment of $d f r$ A resistance gene from $10 \mathrm{E}$. coli isolates (1-10), Pos. (control positive), Neg. (control negative).

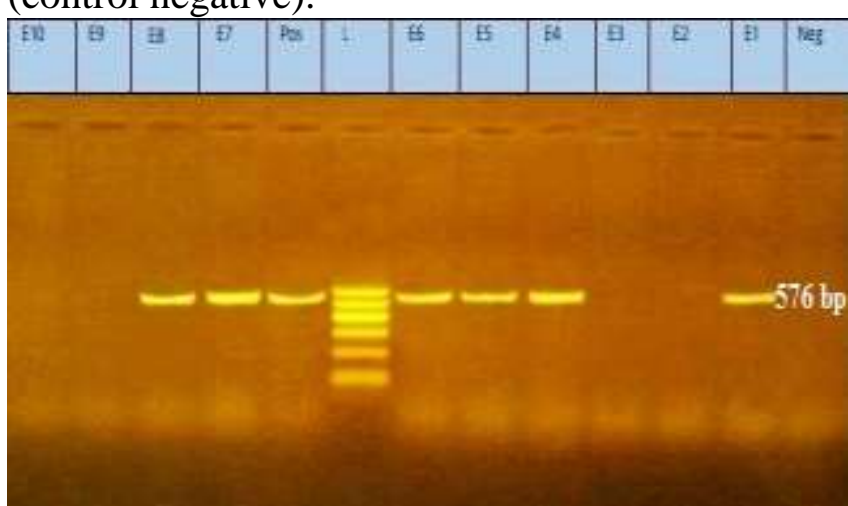

Fig. (4): PCR amplification of the $576 \mathrm{bp}$ fragment of tetA resistance gene from 10 E. coli isolates (1-10), Pos. (control positive), Neg. (control negative).

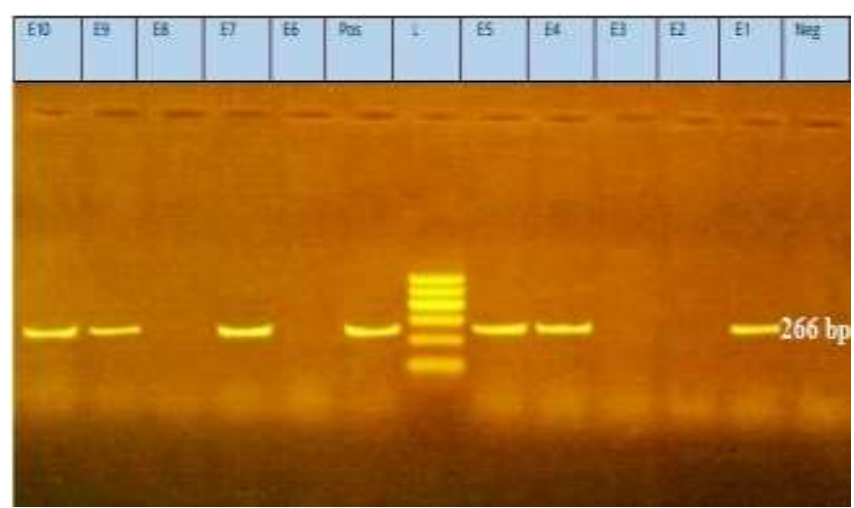

Fig. (6): PCR amplification of the $266 \mathrm{bp}$ fragment of iss virulence gene from $10 \mathrm{E}$. coli isolates (1-10), Pos. (control positive), Neg. (control negative). 


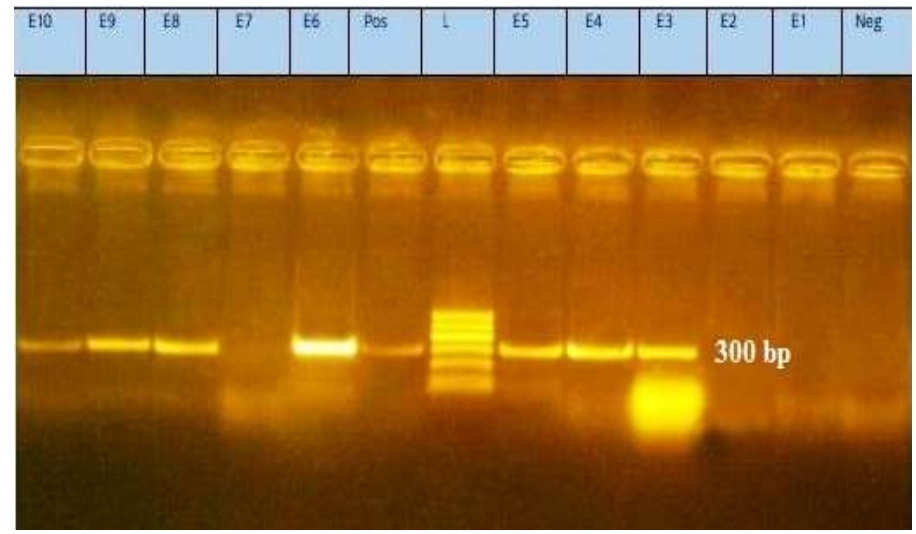

Fig. (7): PCR amplification of the $300 \mathrm{bp}$ fragment of iutA virulence gene from 10 E. coli isolates (1-10), Pos. (control positive), Neg. (control negative).

\section{DISCUSSION}

Avian colibacillosis is one of the most important diseases of chickens, resulting in significant economic losses as well as high morbidity and mortality among baby chicks, broilers and layers (Ewers et al., 2004, Paixão et al., 2016). This syndrome is characterized by acute septicemia with considerable death rates as well as sub-acute forms characterized by multiple organ lesions including airsacculitis and associated pericarditis, perihepatitis and peritonitis (Huja et al., 2015 and Younis et al., 2017). Stress seemed to cause invasion of APEC from intestine into blood stream and spreads into various internal organs and typically causes pericarditis, perihepatitis, peritonitis, salpingitis and other extra-intestinal diseases (Leinter and Heller, 1992).

In the current study, the prevalence of avian colibacillosis was studied in broiler chickens. The results revealed that the prevalence of $E$. coli in the diseased broiler chickens was $29 \%$ as $58 \mathrm{E}$. coli isolates were recovered from 200 diseased broiler chickens. In Egypt, these results were nearly similar to that obtained by Radwan et al. (2020) who recorded a prevalence of $26.7 \%$ in diseased broiler chickens. Other nearly similar results were recorded (Ammar et al., 2011; 24\%, Abd El Tawab et al., 2014; $24.7 \%$, El-Seedy et al., 2019; 23\%). This observation was also was slightly lower than those previously described by Younis et al.
(2017); 36.5\%, and Qurani (2019); 33\%. Higher results were obtained by Roshdy et al. (2012); 43.1\%, and Radwan et al. (2014); $41.5 \%$, Meanwhile, much higher prevalences were recorded including El-Sukhon et al. (2002); 88.2\%, Abd El-Latif (2004); 78.7\%, Abd El Aziz et al. (2007); 90\%, and Radwan et al. (2016); 56\%.

These variations in the $E$. coli prevalence in broilers may be attributed to the difference in strains pathogenicity and virulence beside the severity of the cases as well as the immunological status of the host (Radwan $e t$ al., 2020). Moreover, Ashraf et al. (2015) attributed the variation in $E$. coli prevalence to the difference in the seasons as they recorded higher prevalence in winter $(60.9 \%)$ than that in summer $(41 \%)$. This difference might be due to the lower environmental and hygienic conditions in poultry farms in winter such as overcrowding, bad ventilation and higher ammonia level in air. Also, it might be due to higher percentage of $E$. coli in feed, water, litter and air in winter than in summer. Also, Abd El Tawab et al. (2015) recorded prevalences of $E$. coli in samples from apparently healthy, diseased and freshly dead broiler chickens in winter (15.7\%, $37.1 \%$ and $55 \%$, respectively) and summer seasons $(15.8 \%, \quad 17.5 \%$ and $18.7 \%$, respectively). Stress may cause invasion of pathogenic $E$. coli from intestine into blood stream and spreads into different visceral organs causing peritonitis, perihepatitis, 
pericarditis, salpingitis and other extraintestinal diseases (Leinter and Heller, 1992).

Results of serogrouping of E. coli isolates were illustrated in table (3). Seven Oserogroups were obtained. Serogroups $\mathrm{O}_{125}$ was the most prevalent represented as $31 \%$ followed by serogroups $\mathrm{O}_{158}, \mathrm{O}_{55}, \mathrm{O}_{78}$ as $24.1 \%, 13.8 \%$ and $10.3 \%$, respectively. Then, $\mathrm{O}_{1}$ represented as $6.9 \%$ and finally serogroups $\mathrm{O}_{15}$ and $\mathrm{O}_{8}$ (3.4\%, for each). Moreover, $6.9 \%$ of isolates were untyped with the available antisera. The distribution of $\mathrm{O}$ antigens was nearly similar to that reported in previous studies (Messier et al., 1993; Gomis et al., 2001 and Schouler et al., 2012) who recovered nearly the same serogroups; beside other serogroups. On the contrary they differed from those obtained by Tana et al. (2013) who recovered 8 different serogroups $E$. coli including $\mathrm{O}_{2}, \mathrm{O}_{8}$, $\mathrm{O}_{15}, \mathrm{O}_{73}, \mathrm{O}_{86}, \mathrm{O}_{102}, \mathrm{O}_{115}$ and $\mathrm{O}_{139}$, and Wang et al. (2010) who recovered 8 serogroups; $\mathrm{O}_{65}, \mathrm{O}_{78}, \mathrm{O}_{8}, \mathrm{O}_{120}, \mathrm{O}_{2}, \mathrm{O}_{92}, \mathrm{O}_{108}$, and $\mathrm{O}_{26}$.

Antimicrobial therapy is considered one of the worldwide primary controls for reduction of both morbidity and mortality associated with avian colibacillosis therefore reducing their great losses in the poultry industry (Radwan et al., 2016). Although antimicrobials are considered valuable tools prevent and treat infectious bacterial diseases and as growth promoters at subtherapeutic levels in feeds to maintain health and productivity of birds, its use in livestock production has been implicated as a risk factor in the development and spreading of antibiotic resistance (Gosh and LaPara, 2007). Increasing of antimicrobial resistance is a very important public health concern, and the emergence and spread of antimicrobial resistance is a complex problem driven by numerous interconnected factors. In-vitro antimicrobial sensitivity testing of veterinary pathogens provides valuable guidance to the veterinarian in the choice of appropriate drug treatment (Radwan et al., 2016). Moreover, it is very useful to detect the MDR isolates. Therefore, the appropriate antibiotic should be selected on the basis of its sensitivity that could be detected by laboratory examination.

In the current work, E. coli isolates were tested for their susceptibility to 14 different antimicrobial drugs to detect the drug of choice for treatment as well as to detect MDR isolates for further analyses of the isolates. The results of in-vitro antimicrobial susceptibility tests for $E$. coli isolates were demonstrated in table (4). E. coli isolates showed high sensitivity to colistin sulphate only $(72.4 \%)$. On the other hand, high resistances were recorded against most of the tested antimicrobials especially cefotaxime sodium, florophenicol, apramycin, ciprofloxacin and gentamicin, enrofloxacin, lincomycin and streptomycin $(89.7-96.6 \%)$ as well as sulphamethoxazoltrimethoprim, doxycycline and spiramycin (75.9-77.6\%). MDR was detected in all the tested isolates $(100 \%)$.

Regarding the result of colistin sulphate susceptibility, it was supported by several previous reports in Egypt and worldwide. In Egypt, the current result was the same with those obtained by Radwan et al. (2020) who applied the in-vitro susceptibility on $80 \mathrm{E}$. coli isolates against 11 antimicrobials and found that $70 \%$ of strains were sensitive to colistin meanwhile El-Seedy et al. (2019) found that colistin had the highest sensitivity $(63.6 \%)$.

Regarding the increasing incidences of antibiotic-resistance of $E$. coli isolates in such study; these findings were coincided with those recorded by many authors in Egypt (Abd El Tawab et al. 2014\& 2015; Radwan et al., 2014, 2016 and 2018\& 2020; Awad et al., 2016; El-Shazly et al., 2017; Amer et al., 2018; El-Seedy et al., 2019 and Qurani, 2019). Therefore, no single antimicrobial drug was effective by $100 \%$ against $E$. coli isolates, which might be due to development of resistance due to indiscriminate use of antibiotics (Sharada et al., 2001). 
Moreover, in the current study, MDR was detected in all E. coli isolates (100\%). Such results agreed also with several previous reports in Egypt and all over the world. In Egypt, Amer et al. (2018); Qurani (2019) and Radwan et al. (2020) found that all $E$. coli isolates were MDR. Meanwhile, Radwan et al. (2014) recorded MDR in $90.4 \%$ of isolates.

The spread of MDR bacteria has been recognized as an increasing problem in both medical and veterinary fields, and mobile DNA elements such as plasmids, integrons and transposons favor the proliferation of resistance genes in the bacteria (Speer et al., 1992 and Liebert et al., 1999). Antimicrobial resistance of $E$. coli species is widespread and of concern to poultry veterinarians. This increasing resistance has received considerable attention in Egypt and worldwide. Plasmids are the major vector in the spreading of resistance genes through bacterial population (Radwan et al., 2016). The R-plasmids have been extensively studied in view of the prevalence of MDR (O'Brien et al., 1982). Several virulence and resistance associated genes were reported on plasmids of $E$. coli recovered from diseased poultry (Kelly et al., 2009). There is a wide variety of MDR E. coli and PCR can be used to detect antimicrobial resistance genes in $E$. coli isolates.

In the current work, PCR was applied on 10 MDR E. coli isolates to detect the 3 resistance-associated genes including plasmid-mediated genes for resistance to $\beta$ lactamase (bla $\left.a_{\mathrm{TEM}}\right)$, sulfonamides (sul1), tetracycline (tetA) and trimethoprim ( $d f r \mathrm{~A})$. The results represented in table (5) and figs. (1-4) showed that bla TEM was the most prevalent gene represented in $90 \%$ of the tested isolates, followed by sul $1(70 \%)$, tet A $(60 \%)$ and $d f r \mathrm{~A}(40 \%)$. These results were the same of those reported by Radwan et al., (2016) who recorded bla $a_{T E M}$ gene as the most prevalent found in all isolates $(100 \%)$ followed by sul1(92.9\%), tetA $(35.7 \%)$ and $d f r$ A (21.4\%). Also, these results run parallel to those obtained by Adelowo et al. (2014); bla-TEM (85\%), sul2 (67\%) and tetA (21\%). Also, Momtaz et al. (2012) detected the distribution of antibiotic-resistant genes in $E$. coli isolates from slaughtered commercial chickens as follow tetA (52.63\%), sull (47.36\%) and dfrAl (36.84\%). Moreover, Glenn et al. (2012) detected the four genes in $E$. coli isolates from broilers while Ahmed et al., (2009) detected bla $a_{\text {TEM }}$ and $d f r$ A genes in $E$. coli isolates recovered from retail chicken meat.

Not all APECs are equally virulent. Highly pathogenic APECs generally cause primary infections while less pathogenic strains only cause poultry disease under severe stress conditions including other diseases or environmental stresses leading to compromised host immunity then secondary infections can occur (Radwan et al., 2020). Virulence in APEC is caused by virulence genes present either in the chromosome or on the plasmids (Dozois et al., 2003). Multiple varieties of virulence-associated genes exist and are associated with colibacillosis and several virulence-encoded genes were harbored on plasmids of APEC (Kelly et al., 2009). The highly virulent $E$. coli strains carried at least 4 virulence encoded genes on their largest plasmids (Tivendale et al., 2004).

The virulence mechanisms of APEC were summarized in three steps; adhesion, followed by a multiplication in the host's tissues and finally the evasion of its defense systems (Radwan et al., 2016). APEC strains may produce temperature sensitive haemagglutinin (tsh) which is considered one of the adhesion factors encoded by a $t s h$ gene. This gene is located in ColV plasmids which are frequently found in highly pathogenic avian E. coli and rarely detected in commensal E. coli (Delicato et al., 2003). Because the association of the $t s h$ gene with APEC pathogenicity, Ewers et al. (2004) proposed its utilization as a molecular marker to detect APEC strains. 
Moreover, APEC possesses a number of other virulence factors that enable them to survive in the extra-intestinal tissues of the host. Serum resistance was found to be an important virulence determinant for $E$. coli in chickens and turkeys (Delicato et al., 2003). The iss (increased serum survival) gene is associated with serum resistance and it is significantly more often present in APEC than in commensal E. coli (Vandekerchove, 2004). The iss gene has been identified as a distinguishing trait of avian but not of human (Johnson et al., 2008) and its occurrence in conjugative Col $\mathrm{V}$ plasmid can suggest the relationship of iss factor to the APEC pathogenicity.

APEC strains survive and growth in environments with low iron availability, mainly inside the host, because the expression of iron acquisition systems; like aerobactin, which are associated with virulence in chickens (Vandekerchove, 2004). Most APEC produce aerobactin, while this siderophore is absent in most commensal E. coli (Delicato et al., 2003). The gene encoding aerobactin receptor is called iutA (iron uptake system).

Various studies have highlighted the ability of using some virulence associated genes for identifying APEC strains. They have attempted to detect a common scheme for identification allowing better identification of APEC strains than serotyping. These methods are mainly based on genotyping using PCR methods for the detection of virulence genes carried on colicin V (ColV) plasmids (Radwan et al., 2014). The genotyping methods allow more identification of APEC isolates with higher reliability than the classical serotyping methods used in veterinary labs (Schouler et al., 2012). More than $90 \%$ of the total APEC examined possessed iss, tsh, iut $\mathrm{A}, h l y \mathrm{~F}$ and omp T genes (Radwan et al., 2020).

In the current study, PCR was applied on 10 MDR E. coli isolates to detect 3 virulenceassociated genes including temperature sensitive haemagglutinin gene (tsh), increased serum survival gene (iss) and iron transport encoding gene (iutA). The results represented in tables (5) and figs. (5-7) showed that iutA was the most prevalent represented in $70 \%$ of the tested isolates followed by iss (60\%) and tsh (30\%). These results were nearly similar same of those reported by Radwan et al. (2016) who recorded iutA gene as the most prevalent found in $78.6 \%$ of isolates followed by iss $(71.4 \%)$ and $t s h$ represented as $28.6 \%$. Also, these results were nearly similar to those of Campos et al. (2005) who demonstrated that the $t s h$ gene was found among 25\% APEC strains isolated from chickens with colisepticemia as well as Maurer et al. (1998) who detected the tsh gene among $46 \%$ of the studied APEC strains and in none of the commensal isolates. On the other hand they were opposite to those of Radwan et al. (2014) who reported the prevalence of iss and iutA genes as $75 \%$ and $5 \%$, respectively, Moon et al. (2006); tsh (55\%), iutA (50\%), iss (41\%), and Kwon et al. (2008) who reported that $100 \%$ were carrying iss gene while $94 \%$ were carrying $t s h$ gene. In addition, many authors detected the three genes (Delicato et al., 2003; Tivendale et al., 2004; Ewers et al., 2005; Johnson et al., 2008; Kobayashi et al., 2011 and Radwan et al., 2016).

\section{CONCLUSION}

Colibacillosis is one of the most important diseases of chickens, resulting in significant economic losses as well as high morbidity and mortality. Presence of multidrug resistance pathogens occurred due to the misuse of the antibiotics and is considered a great problem. The prevalence of E. coli in the diseased broiler chickens was $29 \%$. Among 7 O-serogroups were obtained, $\mathrm{O}_{125}$ was the most prevalent represented as $31 \%$. The results of in-vitro antimicrobial susceptibility tests for $E$. coli isolates showed high sensitivity to colistin sulphate only. On the other hand, high resistances were recorded against most of the tested 
antimicrobials. MDR was detected in all the tested isolates $(100 \%)$. The results of PCR in revealed that $90 \%$ of isolates had at least 4 virulence genes while only $10 \%$ had not any gene. The gene blateM was the most prevalent $(90 \%)$ followed by iutA and sul1 (70\% for each) then, iss and tetA $(60 \%$ for each). Meanwhile $d f r A$ and $t s h$ genes were represent in $40 \%$ and $30 \%$ of isolates, respectively.

\section{REFERENCES}

Abd El Aziz, E.E.; Hassan, A.M. and Badr, J.M. (2007): In-vitro efficacy of some antimicrobials on the $E$. coli and Mycoplasma isolates from cases of chronic respiratory disease in broiler in Egypt. Zag. Vet. J., 35(3): 40-49.

Abd El-Latif, M.M. (2004): Escherichia coli associated with swollen head syndrome in broiler chickens". Assuit. Vet. Med. J., 50 (101): 65-77.

Abd El Tawab, A.A.; Ammar, A.M.; Nasef, S.A. and. Reda, R.M. (2015): Antibacterial resistance and resistance gene detriments of $E$. coli isolated from chicken. Benha Vet. Med. J., 28 (2): 231-240.

Abd El Tawab, A.A.; Maarouf, A.A.A.; Abd El $A l$, S.A.; El Hofy, F.I. and El Mougy, E.E.A. (2014): Detection of some virulence genes of avian pathogenic $E$. coli by polymerase chain reaction. Benha Vet. Med. J., 26(2): 159-176.

Adelowo, O.O.; Fagade, O.E. and Agers $\phi, Y$. (2014): Antibiotic resistance and resistance genes in Escherichia coli from poultry farms, southwest Nigeria. J. Infect. Dev. Ctries, 8(9): 1103-1112. doi: $10.3855 /$ jidc. 4222 .

Ahmed, A.M.; Shimabukuro, H. and Shimamoto, T. (2009): Isolation and Molecular Characterization of Multidrug-Resistant Strains of Escherichia coli and Salmonella from Retail Chicken Meat in Japan. J. Food Sci.,74 (7): 405-410.

Amer, M.M.; Mekky, H.M.; Amer, A.M. and Fedawy, H.S. (2018): Antimicrobial resistance genes in pathogenic Escherichia coli isolated from diseased broiler chickens in Egypt and their relationship with the phenotypic resistance characteristics. Vet. World, 11 (8).
Ammar, A.M.; Norhan, K.A.; Yousreya, H.M. and Abd ElAziz, E.E. (2011): Advanced studies on Diagnosis of Single $M$. gallisepticum infection and combined with E. coli in chickens. Zag. Vet. J. (issn.1110-1458).

Ashraf, A.; Samir, A.; Ebtisam, M. and Doaa, A. (2015): Prevalence of E. coli in broiler chickens in winter and summer seasons by application of PCR with its antibiogram pattern. Benha Vet. Med. J., 29: 119-128.

Awad, A.; Arafat, N. and Elhadidy, M. (2016): Genetic elements associated with antimicrobial resistance among avian pathogenic Escherichia coli. Annals of Clin. Microbiol. Atimi., 15(1): 59.

Barnes, H.J.; Nolan, L.K. and Vaillancourt, J.P. (2008): Colibacillosis, p691-732 In Saif YM, Fadly AM, Glisson JR, McDougald LR, Nolan LK, Swayne DE, editors, Diseases of poultry, $12^{\text {th }}$ ed, Blackwell Publishing, Ames, IA .

Barnes, H.J.; Vaillancourt, J.P. and Gross, W.B. (2003): Colibacillosis, p 631-652. In Saif YM, et al. (ed), Diseases of poultry, $11^{\text {th }}$ ed. Iowa State University Press, Ames, IA.

Campos, T.A.; Stehling E.G.; Ferreira A.; Castro A.F.P.; Brocchi M. and Silveira W.D. (2005): Adhesion properties, fimbrial expression and PCR-detection of adhesin-related genes of avian Escherichia coli strains. Vet. Microbiol., 106:275-285.

Chandran, A.; Hatha, A.; Varghese, S. and Mony Sheeja, K. (2008): Prevalence of multiple drug resistant $E$. coli serotypes in a tropical estuary, India. Microbes Environ. 23, (2): 153-158.

Clinical and Laboratory Standards Institute (CLSI) (2016): Performance standards for antimicrobial susceptibility testing, $26^{\text {th }}$ Ed. M100-S.

Collee, J.G.; Fraser, A.G.; Marmion, B.P. and Simmons, A. (1996): Practical Medical Microbiology. $14^{\text {th }} \mathrm{Ed}$.

Colom, K.; Pèrez, J.; Alonso, R.; FernándezAranguiz, A.; Lariňo, E. and Cisterna, $R$. (2003): Simple and reliable multiplex PCR assay for detection of blaTEM, blaSHV and blaOXA.1 genes in Enterobacteriaceae. FEMS Microbiol. Lett., 223: 147-151.

Delicato, E.R.; de Brito, B.G; Gaziri, L.C.J. and Vidotto, M.C. (2003): Virulenceassociated genes in E. coli isolates from 
poultry with colibacillosis. Vet. Microbiol., 94:97-103.

Dozois, C.M.; Daigle, F. and Curtiss, R. (2003): Identification of pathogen specific and conserved genes expressed in-vivo by an avian pathogenic Escherichia coli strain. Proc. Nat. Acad. Sci. USA, 100: 247-252.

El-Seedy, F.R.; Abed, A.H.; Wafaa, M.M.H.; Bosila, A.S. and Mwafy, A. (2019): Antimicrobial resistance and molecular characterization of pathogenic E. coli isolated from chickens. J. Vet. Med. Res., 26 (2): 280-292.

El-Shazly, D.A.; Nasef, S.A.; Mahmoud, F.F. and Jonas, D. (2017): Expanded spectrum $\beta$-lactamase producing Escherichia coli isolated from chickens with colibacillosis in Egypt. Poult. Sci., 96(7): 2375-2384.

El-Sukhon, S.N.; Musa, A. and Al-Attar, M. (2002): Studies on the bacterial etiology of airsacculitis of broilers in northern and middle Jordan with special reference to Escherichia coli, Ornithobacterium rhinotracheale, and Bordetella avium. Avian Dis., 46(3): 605-612.

Ewers, C.; Janßen, T.; Kießling, S.; Philipp, H.C. and Wieler, L.H. (2004): Molecular epidemiology of avian pathogenic Escherichia coli (APEC) isolated from colisepticemia in poultry. Vet. Microbiol., 104(1-2): 91-101.

Ewers, C.; Janßen, T.; Kießling, S.; Philipp, H.C. and Wieler, L.H. (2005): Rapid detection of virulence-associated genes in avian pathogenic Escherichia coli by multiplex polymerase chain reaction. Av. Dis., 49(2): 269-273.

Glenn, L.M.; Englen, M.D.; Lindsey, R.L.; Frank, J.F.; Turpin, J.E. and Berrang M.E. (2012): Analysis of antimicrobial resistance genes detected in multipledrug-resistant Escherichia coli isolates from broiler chicken carcasses. Microb. Drug Resist., 18: 453-463. 10.1089/mdr.2011.0224.

Gomis, S.M.; Riddell, C.; Potter, A.A. and Allan, B.J. (2001): Phenotypic and genotypic characterization of virulence factors of Escherichia coli isolated from broiler chickens with simultaneous occurrence of cellulitis and other colibacillosis lesions. Can. J. Vet. Res., 65:1-6.

Gosh, S. and LaPara, T.M. (2007): The effects of sub-therapeutic antibiotic use in farm animals on the proliferation and persistence of antibiotic resistance among soil bacteria. ISME J, 1: 191-203.

Huja, S.; Oren, Y.; Trost, E.; Brzuszkiewicz, E.; Biran, D.; Blom, J. and Dobrindt, $U$. (2015): Genomic avenue to avian colisepticemia. M. Bio., 6(1); e01681-14.

Huovinen, P.; Sundström, L.; Swedberg, G. and Sköld, O. (1995): Trimethoprim and sulfonamide resistance. Antim. Agents Chemotherapy, 39: 279-289.

Johnson, T.J.; Wannemuehler, Y.M. and Nolan, L.K. (2008): Evolution of the iss gene in Escherichia coli. Appl. Environ. Microbiol., 74: 2360-2369.

Kelly, B.G.; Vespermann, A. and Bolton, D.J. (2009): The role of horizontal gene transfer in the evolution of selected foodborne bacterial pathogens. Food and Chem. Toxicol., 47: 951-968.

Kobayashi, R.K.; Aquino, I.; Ferreira, A.L. and Vidotto, M.C. (2011): EcoR phylogenetic analysis and virulence genotyping of avian pathogenic Escherichia coli strains and Escherichia coli isolates from commercial chicken carcasses in southern Brazil. Foodborne Pathog Dis., 8(5): 631-634.

Kwon, S.G.; Cha, S.Y.; Choi, E.J.; Kim, B.; Song, H.J. and Jang, H.K. (2008): Epidemiological prevalence of avian pathogenic $E$. coli differentiated by multiplex PCR from commercial chickens and hatchery in Korea. J. Bacteriol. Virol., 38(4): 179-188.

Leinter, G. and Heller, E.D. (1992): Colonization of Escherichia coli in young turkeys and chickens. Avian Dis., 36: $211-$ 220.

Liebert, C.A.; Hall, R.M. and Summers, A.O. (1999): Transposon Tn 21, 5 flagship of the floating genome. Microbiol. Mol. Biol. Rev., 63: 507-552.

Maurer, J.J.; Brown, T.P.; Steffens, W.L. and Thayer, S.G. (1998): The occurrence of ambient temperature-regulated adhesions, curli, and the temperature-sensitive hemagglutinin Tsh among avian Escherichia coli. Avian Dis., 42: 106-118.

McKissick, J.C. (2006): Poultry Industry Outlook. The University of Georgia, Athens, USA.

Messier, S.; Quessy, S.; Robinson, Y.; Devriese, L.A.; Hommez, J. and Fairbrother, J.M. (1993): Focal dermatitis and cellulitis in broiler chickens: Bacteriological and 
pathological findings. Avian Dis.; 37: 839-844.

Momtaz, H.; Rahimi, E. and Moshkelani S. (2012): Molecular detection of antimicrobial resistance genes in E. coli isolated from slaughtered commercial chickens in Iran. Veterinarni Medicina, 57(4): 193-197.

Moon, B.M.; Won, G.Y.; Choi, Y.Y; Jin, J.K.; Oh, I.J.; Park, J.H.; Eo, S.K. and Lee, J.H. (2006): Isolation and of characteristics of avian pathogenic Escherichia coli from birds associated with colibacillosis. Chulalongkorn Uni. Fac. Vet. Sc.,pp: 26-29.

O'Brien, A.D.; Newland, J.W.; Miller, S.F.; Holmes, R.K.; Smith, H.W. and Formal, S.B. (1984): Shiga-like toxin-converting phages from Escherichia coli strains that cause hemorrhagic colitis or infantile diarrhea. Sci., 226: 694-696.

Paixão, A.C.; Ferreira, A.C.; Fontes, M.; Themudo, P.; Albuquerque, T.; Soares, M.C. and Corrêa de Sá, M.I. (2016): Detection of virulence-associated genes in pathogenic and commensal avian Escherichia coli isolates. Poult. Sci., 95(7): 1646-1652.

Quinn, P.J.; Markey, B.K.; Carter, M.E.; Donnelly, W.J.C.; Leonard, F.C. and Maguire, D. (2002): Veterinary Microbiology and Microbial Disease. Published by Blackwell. PP. 113-116.

Qurani, R.O. (2019): Phenotypic and genotypic characterization of Trypsin producing Escherichia coli isolated from broiler chickens. Ph. D. Thesis (Microbiology), Fact. Vet. Med., Beni-Suef Univ., Egypt.

Radwan, I.A.; Abed, A.H.; Abd Allah, M.M. and Abd El-Latif, M.A.A. (2018): Bacterial pathogens associated with cellulitis in chickens. J. Vet. Med. Res., 25 (1): 68-79.

Radwan, I.A.; Abed, A.H.; Abd Al-Wanis, S.A.; Abd El-Aziz, G.G. and El-Shemy, A. (2016): Antibacterial effect of cinnamon and oreganium oils on multidrug resistant Escherichia coli and Salmonellae isolated from broiler chickens. J. Egy. Vet. Med, Ass., 76 (2): 169-186.

Radwan, I.A.; Abd El-Halim, M.W. and Abed, A.H. (2020): Genotypic characterization of antimicrobial resistant Escherichia coli isolated from broiler chickens. J. Vet. Med. Res., 27 (2): xxx-xxx.
Radwan, I.A.; Hassan, H.S.; Abd-Alwanis, S.A. and Yahia, M.A. (2014): Frequency of some virulence associated genes among multidrug-resistant Escherichia coli isolated from septicemic broiler chicken. Int. J. Adv. Res., 2(12): 867-874.

Randall, L.P.; Cooles, S.W.; Osborn, M.K.; Piddock, L.J.V. and Woodward, M.J. (2004): Antibiotic resistance genes, integrons and multiple antibiotic resistance in thirty-five serotypes of Salmonella enterica isolated from humans and animals in the UK. J. Antim. Chemother., 53: 208-216.

Roshdy, H.; El-Aziz, S.A. and Refai, M. (2012): Incidence of $E$. coli in chickens and ducks in different governorates in Egypt. In $1^{\text {st }}$ conference Anim. Hlth. Res. Inst. Assoc. (pp. 420-426).

Russo, T.A. and Johnson, J.R. (2000): Proposal for a new inclusive designation for extraintestinal pathogenic isolates of Escherichia coli: ExPEC. J. Infec. Dis., 181(5): 1753-1754.

Sabarinath, A.; Tiwari, K.P.; Deallie, C.; Belot, G.; Vanpee, G.; Matthew, V.; Sharma, R. and Hariharan, H. (2011): Antimicrobial resistance and phylogenetic Groups of commensal Escherichia coli isolates from healthy pigsin Grenada. Available from: www.webmedcentral.com.

Saif, Y.M.; Barnes, H.J.; Glisson, J.R., Fadly, A.M.; Dougland, L.R. and Swayne, D.E. (2003): Diseases of Poultry, $11^{\text {th }}$ ed. Pp: 562-566. Press Iowa State, USA.

Schouler, C.; Schaeffer, B.; Bree, A.; Mora, A.; Dahbi, G.; Biet, F.; Oswald, E.; Mainil, J.; Blanco, J. and Moulin-Schouleur, M. (2012): Diagnostic strategy for identifying avian pathogenic Escherichia coli based on four patterns of virulence genes. J. Clin. Microbiol.; 50: 167-1678.

Sharada, R.; Krishnappa, G. and Upendra, H.A. (2001): Serological (O) grouping and drug susceptibility of Escherichia coli strains from chicken. Ind. J. Vet., 78: 78-79.

Speer, B.S.; Shoemaker, N.B. and Salyers, A.A. (1992): Bacterial resistance to tetracycline: mechanisms, transfer, and clinical significance. Clin. Microbiol. Rev., 5: 387-439.

Tana, S.K.; Elena, C.; Pranvera, A.S. and Antonio, C. (2013): Serotyping and biotyping prevalence of avain pathogenic E. coli in Albanian poultry industry. 
Agriculture University of Tirana, Faculty of Veterinary Medicine, Albania and Universita degli Studi "Aldo Moro", Facolta di Medicina Veterinaria, Italy 1098-1104.

Tivendale, A.K.; Joanne, L.A.; Carol, A.G.; Brendan, S.C. and Glenn, F.B. (2004): Association of iss and iucA, but not $t s h$, with plasmid mediated virulence of avian pathogenic E. coli. Infec. Immun., P. 6554-6560.

Vandekerchove, D. (2004): Colibacillosis in battery-caged layer hens: Clinical and bacteriological characteristics and risk factor analysis. Ph. D. Thesis in Vet. Sci., Ghent Univ., Belgium.

Wang, X.M.; Liao, X.P.; Zhang, W.J.; Jiang, H.X.; Sun J.; Zhang M.J.; He, X.F.; Lao, D.X. and Liu, Y.H. (2010): Prevalence of serogroups, virulence genotypes, antimicrobial resistance, and phylogenetic background of avian pathogenic
Escherichia coli in south of China. Food borne Pathog Dis.; 7(9): 1099-106.

Yaguchi, K.; Ogitani, T.; Osawa, R.; Kawano, M.; Kokumai, N.; Kaneshige, T.; Noro, T.; Masubuchi, K. and Shimizu, Y. (2007): Virulence Factors of Avian Pathogenic Escherichia coli Strains Isolated from Chickens with Colisepticemia in Japan. Avian Dis., 51(3): 656-662.

Younis, G.; Awad, A. and Mohamed, N. (2017): Phenotypic and genotypic characterization of antimicrobial susceptibility of avian pathogenic Escherichia coli isolated from broiler chickens. Vet. World, 10(10): 1167.

Yue, H.; Qing, L.; Willias, S.; Kang, L.; Pei, L.; AnChun, C.; QingKe, K. (2018): A bivalent vaccine derived from attenuated Salmonella expressing O-antigen polysaccharide provides protection against avian pathogenic Escherichia coli $\mathrm{O}_{1}$ and $\mathrm{O}_{2}$ infection. Vaccine, 36(8): 1038-1046.

\title{
دراسات بكتريولوجية وجزيئية عن الايشيريشيا كولاي المعزولة من بداري التسمين

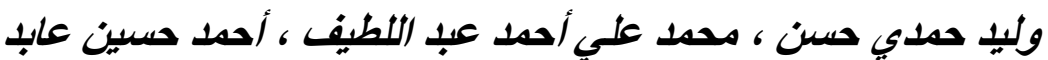

E-mail: aboabedelmasry@yahoo.com,ahmed.moawad@vet.bsu.edu.eg Assiut University web-site: www.aun.edu.eg

\begin{abstract}
تعتبر الاصابة بالميكروب القولوني أحد أهم الأمر اض التي تصيب الدجاج ، مما يؤدي إلى خسائر اقتصادية عالية ، فضلاً

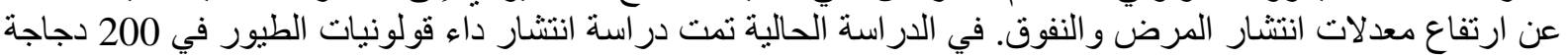

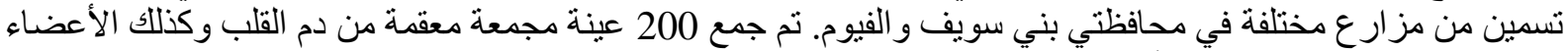

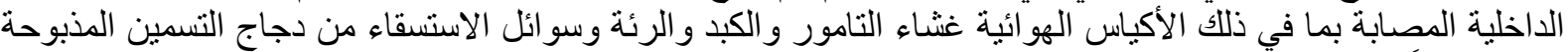

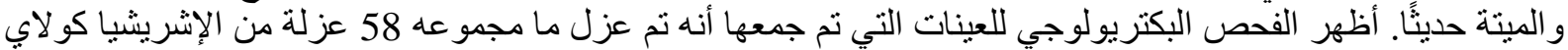

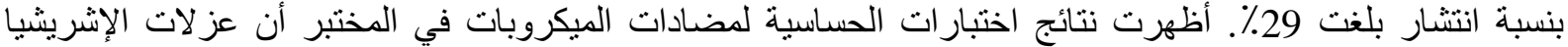

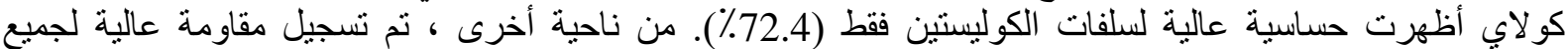

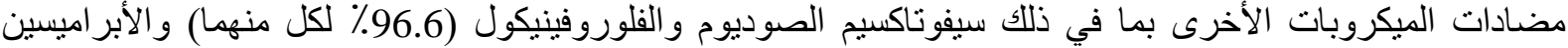

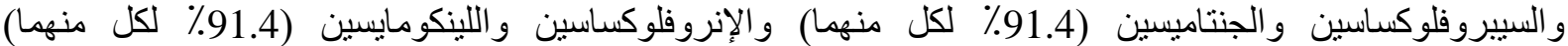

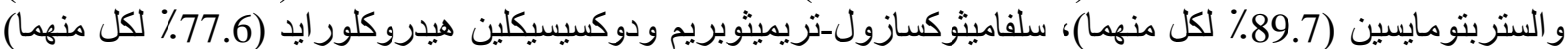

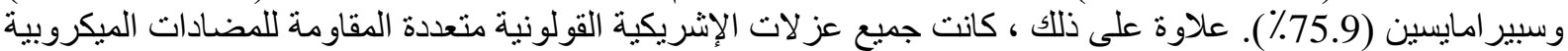

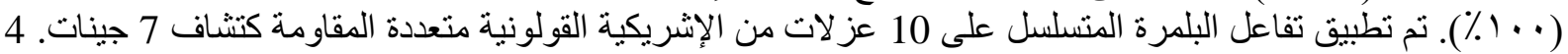

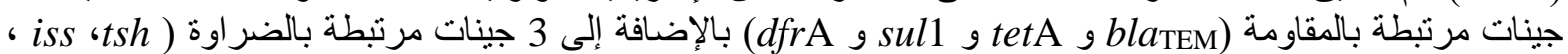

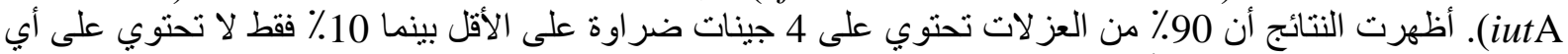

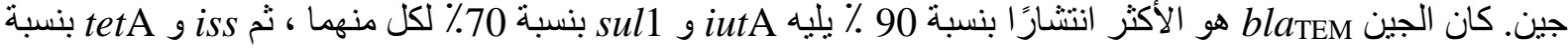

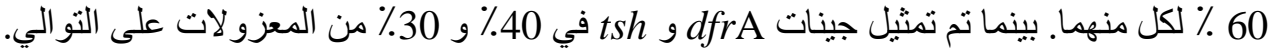

